DOI: 10.46340/eppd.2021.8.2.16

Dmytro Yadchenko

ORCID ID: https://orcid.org/0000-0002-6451-7338

Institute of Public Administration and Research in Civil Protection, Kyiv, Ukraine

\title{
DEVELOPMENT AND MODERN INTERNATIONAL EXPERIENCE OF AEROMEDICAL EVACUATION AS A MECHANISM FOR PROTECTION OF VICTIMS
}

\author{
Дмитро Ядченко \\ Інститут державного управління та наукових досліджень з цивільного захисту, \\ Київ, Україна

\section{РОЗВИТОК ТА СУЧАСНИЙ МІЖНАРОДНИЙ ДОСВІД АЕРОМЕДИЧНОЇ ЕВАКУАЦІЇ ЯК МЕХАНІЗМУ ЗАХИСТУ ПОСТРАЖДАЛИХ}

\begin{abstract}
In accidents, catastrophes and emergencies, there may be circumstances where the needs of the injured or sick exceed the capacity of local medical facilities, or access to them is impossible, or the number of victims exceeds the number of available seats. The emergency situation may occur in a place where access to land transport is difficult or impossible. Situations in which immediate assistance is needed, also occur in mountainous areas and at sea, where it is simply impossible to reach by road. In such cases, time plays a special role and the use of aircraft becomes the key to saving the lives of victims. Aeromedical evacuation can play a key role in bringing real assistance closer and becoming an effective mechanism for protecting victims. The article describes the history of the first attempts to transport the wounded by air and the history of the development of aeromedical evacuation, starting from the first flights. Military experience is analyzed, in particular the first attempts to carry out aeromedical evacuation during the First World War and the spread of the use of medical aircraft during the Second World War. The experience of the military conflicts in Korea and Vietnam was reviewed, which gave the greatest impetus to the development of air transport of the wounded. The connection is established between the development of aeromedical evacuation in the military sphere and its application in the interests of the civilian population. The modern world experience of using aeromedical evacuation as a mechanism of protection of victims is researched. Models of organization and financing of aeromedical evacuation of the leading countries of the world (USA, Great Britain, France, Germany) are analyzed. Optimal solutions are proposed of solving the issues of organizing aeromedical evacuation to Ukraine.
\end{abstract}

Keywords: aeromedical evacuation, medical aviation, evacuation, emergency situations, victims protection.

Постановка проблеми. Евакуація постраждалих повітряним транспортом, знайшла широке застосування у світі. В розвинених країнах успішно працюють спеціальні служби (підрозділи) у системі охорони здоров'я, що забезпечують доставку постраждалих, або важкохворих авіаційним транспортом. Таку евакуацію постраждалих з місця події у світі прийнято називати аеромедичною евакуацією (далі - AME). В Україні АME визначають як транспортування постраждалих (хворих) до закладів охорони здоров'я авіаційним транспортом з наданням за потреби належної медичної допомоги на борту повітряного судна ${ }^{1}$.

\footnotetext{
${ }^{1}$ Наказ Про організачію та проведення аеромедичної евакуачії повітряними суднами Державної служби Украӥни з надзвичайних ситуацій, Національної гвардї̈ Украӥни та Державної прикордонної служби України, 2018 (МВС). Офічійний сайт Верховної Ради Украӥни <https://zakon.rada.gov.ua/laws/show/z0285-18> (2021, лютий, 19).
} 
Питання здійснення АМЕ в Україні наразі $\epsilon$ актуальним, особливо враховуючи перевантаженість системи охорони здоров'я, у зв'язку з епідемією. Вивчення світового досвіду надає можливість проаналізувати можливості України уданому напрямі та імплементувати кращі принципи AME, що застосовують провідні держави світу.

Аналіз останніх досліджень і публікацій. Досвіду в області застосування авіаційного транспорту для евакуації поранених і постраждалих в різних ситуаціях приділяється достатня увага науковців. АМЕ присвячені роботи А. Эни, I. Луріна, А. Короля, П. Волянського, Nicholas G. Lezama, Lawrence M. Riddles, William A. Pollan, Leonardo C. Profenna. В той же час, більша частина науковців в основному приділяє увагу АМЕ в умовах бойових дій. На даний час в Україні ведеться активна робота щодо використання авіації для надання допомоги хворим та постраждалим в надзвичайних ситуаціях (далі- НС). Тому дослідження світового досвіду АME на сьогодні $€$ актуальним.

Мета статті полягає у висвітленні історії розвитку AME та вивчення військового і цивільного міжнародного досвіду транспортування поранених та постраждалих повітряним транспортом як механізму захисту постраждалих.

Виклад основного матеріалу. Про підкорення неба людство мріяло ще 3 прадавніх часів, починаючи від міфу про Дедала та Ікара і перших наукових праць Да Вінчі. Вперше ж в історії реальний політ здійснили брати Монгольф'єр на повітряній кулі 19 вересня 1784 року (Франція). 3 цього моменту прийнято вести відлік початку активного освоєння людиною повітряного простору. Можливість людини підніматись у повітря в першу чергу зацікавила військових, а згодом польоти увійшли і в інші сфери життя. Сьогодні важко уявити сучасний світ без польотів.

Саме з використанням повітряної кулі і розпочинаються перші намагання перевезення поранених повітрям. Першу таку спробу приписують події, що сталася у 1870 році під час Пруссько-Французької війни, під час облоги Парижа, коли вдалося евакуювати на повітряних кулях 160 поранених, хоча на сьогоднішній день думки істориків розходяться щодо правдивості цієї історії.

Як і багато інших нововведень, АMЕ зародилась в армії. Сама концепція використання повітряного судна для надання допомоги пораненим виникла майже одразу від початку використання літаків у військових цілях. Першою, справжньою та задокументованою АMЕ прийнято вважати випадок 1917 року на Синайському півострові. Британський біплан BE-2c, що належав до Королівського літаючого корпусу евакуював пораненого у щиколотку солдата з Верблюжого королівського корпусу, під час польоту тривалістю 45 хвилин. Аналогічна евакуація наземним шляхом (в ті часи поранених транспортували на імпровізованих тканинних ношах, що прив'язувались ззаду до верблюда та тягнулись по землі) зайняла би близько $3-x$ днів ${ }^{1}$.

У тому ж 1917 році з'являється перший літак, спеціально призначений для медичної евакуації поранених і хворих французький - «AR II». Тобто ідея щодо транспортування поранених повітрям знайшла своє продовження.

Вже у 1920-х роках Великобританія та Франція під час своїх африканських кампаній та на Близькому Сході організовано застосовують АME. Здебільшого для таких польотів використовували літаки Airco DH-9A де позаду пілота, розміщувались одинарні ноші для пораненого. У такий спосіб було евакуйовано близько 7000 солдат.

У період Другої світової війни санітарну авіацію та AME вже застосовують в усіх арміяхучасниках війни. Тільки авіація США евакуювала авіаційним транспортом більше 1 млн. поранених. Широко застосовувала авіацію для таких цілей і Німеччина, тільки з Польщі авіаційним транспортом було евакуйовано більше 25 тис. поранених ${ }^{2}$.

Після закінчення Другої світової війни у всьому світі починається серійне виробництво нового типу повітряних суден - вертольотів. Їх висока мобільність та можливість здійснювати зліт та посадку на обмежених площах відкриває нову еру в авіації та перспективи для розвитку AМЕ. Масове використання вертольотів для евакуації поранених до шпиталів застосовує армія США у збройному конфлікті у Кореї (1950-1953 роки), причому евакуація здійснюється прямо з передової.

\footnotetext{
${ }^{1}$ Dolev, E. (1986). The First Recorded Aeromedical Evacuation in the British Army - The True Story. J R Anny Med Corps, 132, 34-36.

${ }^{2}$ Olson, C. M., Bailey, J., Mabry, R., Rush, S., Morrison, J. J., Kuncir, E. J. (2013). Forward aeromedical evacuation: A brief history, lessons learned from the Global War on Terror, and the way forward for US policy. Journal of Trauma and Acute Care Surgery, 75 (2), 130-136.
} 
Для виконання таких завдань застосовувались спеціальні вертольоти «Bell-47» із зовнішнім розташуванням ношів. AME здійснювалась до медичного морського судна «Respons \& Consolation», на палубі якого передбачили спеціально обладнані посадкові майданчики. Один вертоліт міг евакуювати двох поранених бійців. За час ведення бойових дій таким чином було евакуйовано понад 17 тисяч поранених. Завдяки AME під час ведення бойових вдалося значно скоротити смертність особового складу. Такі успіхи стали можливими завдяки розробленню спеціальної програми 3 проведення АМЕ в армії США.

Під час війни у В'єтнамі AME вже приділяється особлива увага. Застосування літаків і вертольотів для проведення такого заходу зростає у рази. У медичному забезпеченні бойових дій особлива роль відводилась авіаційному транспорту. Накопичення та узагальнення такого досвіду дозволило згодом створити повноцінну систему АМЕ в арміях США та країн НАТО. Така система дає змогу безпечно надавати медичну допомогу пораненим, за рахунок розташування лікувальних закладів далеко від району ведення бойових дій. Загалом застосування АМЕ під час ведення бойових дій у Кореї та В'єтнамі надало змогу зменшити втрати у 2 рази в порівнянні з Другою світовою війною1.

Висока ефективність застосування вертольотів для евакуації поранених під час бойових дій спонукала до застосування AME в інтересах цивільного населення. Транспортування постраждалих у різноманітних аваріях та катастрофах і важких пацієнтів по повітрю могло значно скоротити прибуття медиків до потерпілого та його доставки до лікарні, а отже значно наблизити реальну допомогу постраждалим.

Експериментом по застосуванню AME в інтересах захисту населення став проєкт під назвою Military Assistance to Safety and Traffic (MAST) який у 1969 році розпочали в США. Його метою стало вивчення можливостей використання військового досвіду AME в умовах бойових дій та апроксимувати його на цивільну сферу. Військові вертольоти, пілоти та медики залучались для надання медичної допомоги постраждалим в дорожньо-транспортних аваріях. Постраждалих доставляли як у цивільні лікарні, так і до військових шпиталів, по принципу найближчого розташування до місця події.

Станом на травень 1972 року, в рамках проєкту було здійснено 1049 польотів, із загальним нальотом 2224 години та транспортовано 1297 постраждалих. Проєкт підтвердив високу ефективність застосування АМЕ у таких випадках.

Але в той же час досвід показав, що для AME в мирний час необхідно застосовувати інші підходи. Зокрема, використання багатоцільових військових вертольотів не надає змогу в повній мірі надавати допомогу постраждалим і слід використовувати спеціально обладнані повітряні судна, особливо у випадках, коли немає необхідності у транспортуванні великої кількості постраждалих. Також висновки стосувались підготовки персоналу для здійснення процедур АМЕ. Проєкт був продовжений. Таким чином, за 1969-1978 роки в Сан-Антоніо (Техас) силами MAST були евакуйовані і доставлені з місця події до військового госпіталю понад 16 тисяч постраждалих ${ }^{2}$.

Завдяки висновкам, що були зроблені під час роботи MSAT було вирішено застосовувати AME як механізм захисту постраждалих. У подальшому, в США, на державному рівні почали активно впроваджувати AME, розвивати цивільну санітарну авіацію, основу якої склали парамедики і медичні сестри, що постійно працюють на спеціально обладнаних вертольотах.

В даний час зберігається тенденція до розширення використання санітарної авіації. В США кількість цивільних вертольотів медичного призначення перевищує 700 машин. Всі стаціонари, які мають статус травматологічного центру першого рівня, мають вертолітні майданчики. Передбачена також можливість дозаправки ПС на таких майданчиках.

Щодо запровадження AME у Великобританії, то ще у 1933 році тут вперше в світі створено службу цивільної санітарної авіації. Основним іiї завданням було обслуговування острівної частини Шотландії, яка була важкодоступною для іншого транспорту.

У Великобританії працює декілька організацій, які мають медичні вертольоти для екстреної евакуації в стаціонари ${ }^{3}$. В Шотландії базуються вертольоти і літаки медичного призначення, їх робота фінансується з державного бюджету.

\footnotetext{
1 Tам само.

${ }^{2}$ MAST (Military Assistance to Safety and Traffic) (July-December 1970). Report of Test Program by the Interagency Study Group <https://profiles.nlm.nih.gov/spotlight/rm/catalog/nlm:nlmuid-101584666X962-doc> (2021, лютий, 19).

${ }^{3}$ Black, J. J., Ward, M. E., Lockey ,D. J. (2004). Appropriate use of helicopters to transport trauma patients from incident scene to hospital in the United Kingdom: an algorithm. Emergency Medicine, 21, 355-361.
} 
У шотландській санітарній авіації працюють фахівці з середньою медичною освітою. У графствах Вілтшир і Суссекс вертольоти знаходяться в спільному користуванні медичної служби і місцевих підрозділів поліції, на них також працюють медики без вищої спеціальної освіти. Тільки в складі Екстреної вертолітної медичної служби Лондона використовується медичний вертоліт, в бригаду якого входить лікар і медсестра.

Серед всіх викликів медичного вертольоту служби HEMS Лондона більше половини складають надання екстреної допомоги потерпілим у дорожньо-транспортних пригодах, інші - постраждалі при падінні з висоти, а також при вогнепальних і ножових пораненнях. В інших частинах Великобританії медичні вертольоти набагато рідше використовуються для екстреної допомоги потерпілим у дорожньо-транспортних пригодах - не більше $30 \%$ вильотів санітарної авіації.

Франція має добре розвинену систему надання екстреної медичної допомоги, в яку входить служба санітарної авіації, що має в своєму складі лікарський персонал. Кожен регіон в країні має головний офіс екстреної медичної допомоги (Services de I 'Aide Medicale Urgent, SAMU), що базується в одному з великих стаціонарів обласного значення, де $\epsilon$ диспетчерська, обладнані вертолітні майданчики та інші спеціальні служби. Персонал SAMU складається з лікарського і фельдшерського складу, радіотелефоністів і адміністраторів. До складу регіональної системи SAMU входять периферичні підстанції лікарських бригад швидкої допомоги, які для своєї роботи можуть використовувати як наземний, так і вертолітний транспорт.

У SAMU цілодобово чергують відповідальні лікарі, які отримують виклики від населення і уповноважені приймати рішення про направлення до місця події медичні бригади на наземному транспорті, або на вертольоті. Використовуються різноманітні моделі медичних вертольотів. Вони розрізняються по дальності дії, швидкості польоту, евакуаційної місткості. Географічне розташування SAMU дозволяє скоротити час шляху для бригади швидкої допомоги до 10 хвилин. Відповідальний лікар SAMU в разі гострої необхідності має право використовувати для доставки медичних бригад до місця події вертольоти, що належать силовим відомствам Франції ${ }^{1}$.

Перша програма по використанню медичних вертольотів в Німеччині була розроблена німецькою автомобільною асоціацією (ADAC) в зв'язку з ростом числа дорожньо-транспортних пригод на дорогах країни в кінці 80 -х - початку 90 -х років минулого століття. В даний час в країні $\epsilon$ понад 50 вертолітних майданчиків, велика частина яких розташована біля великих стаціонарів. «Зона відповідальності» вертолітного майданчика - 50-70 км, що дозволяє досягти найбільш віддалених точок в даній зоні за 8 хвилин.

У деяких областях Німеччини час «підльоту» для медичних вертольотів навіть менше наприклад, в Мюнхені радіус дальності польоту становить 30 км.

До складу бригади медичних вертольотів завжди включають лікаря, а також медичну сестру або парамедика. Евакуація постраждалих після надання їм необхідної медичної допомоги може здійснюватися як «по повітрю», так і наземним транспортом, так як у всіх випадках дорожньотранспортних пригод разом з вертольотом на місце події направляють бригаду наземної служби швидкої допомоги. Рішення про направлення медичного вертольоту на місце події приймає Центр по контролю рятувальних операцій.

Швейцарська авіаційна служба порятунку (REGA) була заснована в 1979 році, оскільки в гірських районах складно використовувати наземну систему швидкої допомоги. Найбільш частий привід до вильотів в гірську частину країни - надання медичної допомоги при травмах у альпіністів і спортсменів-гірськолижників, в рівнинній частини Швейцарії медичні вертольоти задіяні в основному при наданні допомоги потерпілим у дорожньо-транспортних пригодах.

До 2000 року до складу REGA входить 15 сучасних пошуково-рятувальних вертольотів, які базуються на 11 майданчиках. Медичні вертольоти мають допуск до цілодобових польотів, на борту кожного вертольоту знаходяться пілот, лікар і парамедик. Протягом року відбувається близько 7 тисяч екстрених вильотів до постраждалих i близько 2 тисяч міжгоспітальних перевезень хворих.

Протягом другої половини ХХ століття, практично в усіх промислово розвинених державах вертольоти медичного призначення стали відігравати значиму роль у механізмі захисту постраждалих в наслідок НС та хворих.

\footnotetext{
${ }^{1}$ Guénot, P., Leigh-Smith, S., Granger-Veyron, N. (2019). The involvement of the French military medical service in helicopter rescue missions for Emergency Medical Aid at Sea: the current situation and prospects for the future. Journal of The Royal Naval Medical Service, 105, 95-102.
} 
Досвід показав, що надання медичної допомоги медперсоналом санітарного вертольоту веде до зниження смертності на 25\%, при цьому часто відзначається більш високий рівень професіоналізму бортових медиків у порівнянні з їх колегами наземної служби швидкої допомоги. Такі обставини здійснюють відповідний вплив як на обсяг, так і на якість допомоги, що здійснюється на місці події.

\section{Висновки та перспективи подальших досліджень.}

3 міжнародного досвіду відомі наступні критерії застосування AME в інтересах населення:

- час прибуття автомашини швидкої медичної допомоги до місця події більше, ніж час прибуття вертольоту більш ніж на 10 хвилин;

- число постраждалих в дорожньо-транспортних пригодах перевищує можливості надання їм допомоги бригадою автомобіля швидкої медичної допомоги;

- найближче до місця події лікувально-профілактичний заклад закрито для прийому пацієнтів 3 травмою;

-є перешкоди для під'їзду автомобіля до місця події.

Міждержавні відмінності в організації AME за участю вертольотів медичного призначення стосуються:

- освітнього рівня медичного персоналу і, як наслідок, обсягу медичної допомоги, що надається бригадою;

-технічних особливостей вертольотів, а також режиму їх експлуатації (цілодобово, тільки в світлий час доби і ін.).

Щодо організації та фінансування АМЕ постраждалих у НС та для транспортування хворих у світі практикують різні підходи та моделі.

У деяких країнах завдання з АМЕ та організацію служби санітарної авіації бере на себе держава. Як правило, уряд таких держав створює спеціальні служби санітарної авіації з своїм фінансуванням, такі служби створені урядами США, Франції, Польщі.

Популярним $\epsilon$ також державно-приватне партнерство. Державою укладаються угоди 3 приватними перевізниками, наприклад чартерними авіакомпаніями для транспортування хворих, або постраждалих внаслідок НС чи аварій до закладів охорони здоров'я. Такі послуги можуть замовлятись в окремому випадку термінової необхідності транспортування хворого/постраждалого, або ж укладання довгострокових угод по чергуванню приватних повітряних суден для здійснення AME в інтересах місцевих пошуково-рятувальних та медичних служб. У таких випадках, з боку держави встановлюються конкретні правила та процедури укладання таких договорів і залучення послуг приватних авіакомпаній, включаючи контроль експлуатаційних та супутніх витрат. Але в цілому оперативне управління системою АМЕ залишається, як правило представникам авіаційних, пошуково-рятувальних та медичних служб.

У деяких країнах AME фінансують приватні компанії та асоціації. Такі приклади поширені в Свропі. Так, наприклад у Лондоні приватна компанія Virgin Corporation фінансує чергування медичного вертольоту в інтересах служби екстреної медичної допомоги у порядку благодійності. Яскравим прикладом $є$ також автомобільна асоціація ACAD у Німеччині.

Поширеним $\epsilon$ також досвід використання багатоцільових повітряних суден, цільовим призначенням яких є здійснення пошуково-рятувальних операцій, або військових літаків та вертольотів. Така практика особливо розповсюджена при ліквідації наслідків масштабних НС. В умовах аеродрому базування, не складно переобладнати будь-який транспортний літак, або вертоліт у санітарний варіант з ношами, для того, щоб розмістити там постраждалих 3 не важкими травмами і швидко доставити їх до медичних закладів.

У світі немає єдиної загальноприйнятої моделі фінансування АМЕ. Ось деякі з них:

- урядове фінансування (бюджет) - Франція;

- добровільні пожертвування (спонсорство) - Великобританія;

- членські внески (добровільне членство) - Швейцарія;

- змішане фінансування - США, Німеччина та ін.

Найбільш поширена практика використання змішаної моделі. Провідні країни світу використовують різні способи організації та фінансування АME для наближення реальної допомоги постраждалим в НС та простих аваріях.

Хорошим прикладом для наслідування $є$ використання пошуково-рятувальних та військових повітряних суден для здійснення АМЕ різного характер. Враховуючи успішний досвід застосування 
такого підходу у багатьох країнах та досвід ліквідації наслідків НС із застосуванням авіації, використання змішаної системи AME, де чергові пошуково-рятувальні повітряні судна будуть використовуватись як для проведення авіаційних робіт з пошуку і рятування, так і для AME, $\epsilon$ оптимальним. Враховуючи, що в Україні ще з 1997 року впроваджена та успішно працює Єдина система проведення авіаційних робіт з пошуку і рятування із організацією цілодобового чергування пошуково-рятувальних повітряних суден, залучення повітряних суден цієї системи до проведення AME моголо б бути одним із найбільш раціональних та економічно вигідних варіантів повноцінної реалізації AME в Україні. Такому сприяє також наявність на чергових повітряних суднах системи екіпажів з підготовленими авіаційними рятувальниками (у тому числі з медичною освітою), які навчені діяти в будь-яких умовах у тому числі і НС, чого не можна сказати про медичні бригади, які необхідно залучати окремо.

\section{References:}

1. Nakaz Pro orhanizatsiyu ta provedennya aeromedychnoyi evakuatsiyi povitryanymy sudnamy Derzhavnoyi sluzhby Ukrayiny z nadzvychaynykh sytuatsiy, Natsionalnoyi hvardiyi Ukrayiny ta Derzhavnoyi prykordonnoyi sluzhby Ukrayiny, 2018 (MVS) [Order on the organization and conduct of aeromedical evacuation by aircraft of the State Emergency Service of Ukraine, the National Guard of Ukraine and the State Border Guard Service of Ukraine, 2018 (MIA)]. Ofitsiynyy sayt Verkhovnoyi Rady Ukrayiny [Official site of the Verkhovna Rada of Ukraine] <https://zakon.rada.gov.ua/laws/show/z0285-18> (2018, February, 19). [in Ukrainian].

2. Dolev, E. (1986). The First Recorded Aeromedical Evacuation in the British Army - The True Story. J R Anny Med Corps, 132, 34-36. [in English].

3. Yena, A. I., Lurin, I. A., Kravchuk, V. V. (2010). Aeromedychna evakuaciya [Aeromedical evacuation]. Ternopil: TDMU. [in Ukrainian].

4. Olson, C. M., Bailey, J., Mabry, R., Rush, S., Morrison, J. J., Kuncir, E. J. (2013). Forward aeromedical evacuation: A brief history, lessons learned from the Global War on Terror, and the way forward for US policy. Journal of Trauma and Acute Care Surgery, 75 (2), 130-136. [in English].

5. MAST (Military Assistance to Safety and Traffic) (July-December 1970). Report of Test Program by the Interagency Study Group <https://profiles.nlm.nih.gov/spotlight/rm/catalog/nlm:nlmuid-101584666X962-doc> (2021, February, 19). [in English].

6. Guénot, P., Leigh-Smith, S., Granger-Veyron, N. (2019). The involvement of the French military medical service in helicopter rescue missions for Emergency Medical Aid at Sea: the current situation and prospects for the future. Journal of The Royal Naval Medical Service, 105, 95-102. [in English].

7. Lezama, N. G., Riddles, L. M., Pollan, W. A., Profenna, L. C. (2011). Disaster Aeromedical Evacuation. Military medicine, 176, 1128-1132. [in English].

8. Black, J. J., Ward, M. E., Lockey, D. J. (2004). Appropriate use of helicopters to transport trauma patients from incident scene to hospital in the United Kingdom: an algorithm. Emergency Medicine, 21, 355-361. [in English]. 